Biol. Stud. 2021; 15(4): 3-16 • DOI: https://doi.org/10.30970/sbi.1504.666

www.http://publications.Inu.edu.ua/journals/index.php/biology

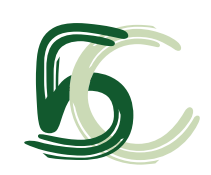

UDC: $577.325 .2,57.042 / 043$

\title{
PEROXIDASE ACTIVITY OF ERYTHROCYTES HEMOGLOBIN UNDER ACTION OF LOW-FREQUENCY VIBRATION
}

\author{
O. I. Dotsenko
}

Vasyl' Stus Donetsk National University, 21 600-richya St., Vinnytsia 21021, Ukraine

Dotsenko, O. I., Taradina, G. V., \& Mischenko, A. M. (2021). Peroxidase activity of erythrocytes hemoglobin under action of low-frequency vibration. Studia Biologica, 15(4): 3-16 • DOI: https:// doi.org/10.30970/sbi.1504.666

Background. Hemoglobin is a hemoprotein which in the presence of oxidative equivalents, such as $\mathrm{H}_{2} \mathrm{O}_{2}$, can act as peroxidase with a very high oxidative potential. Hemoglobin oxidation is accompanied by generation of highly oxidized forms of iron and globin radicals that have high oxidative activity and are toxic to cells. In addition, peroxidase activity may indicate structural changes that occur in the hemoglobin molecule as a result of chemical modification.

Materials and Methods. Erythrocyte suspension was subjected to vibration for $3 \mathrm{~h}$ within the frequency range from 8 to $32 \mathrm{~Hz}$ with amplitudes of $0.5 \pm 0.04$ and $0.9 \pm 0.08 \mathrm{~mm}$. At certain intervals, hemoglobin peroxidase activity was determined together with the content of its ligand forms in the hemolysates of cells. Additionally, experiments were performed to investigate the mechanism and calculate the kinetic parameters of peroxidase reaction.

Results and Discussion. Experimental data on low-frequency vibrations effect on erythrocyte hemoglobin peroxidase activity were analyzed. The kinetics of the oxidation reaction of $p$-phenylenediamine by hemoglobin in erythrocytes was studied. It was found that peroxidase oxidation has a ping-pong mechanism. The kinetic parameters of the peroxidase reaction involving hemoglobin were determined. The change of kinetic parameters after two-hour exposure to the incubation medium and low-frequency vibration was studied. A possible mechanism of action of hemoglobin in oxidation reactions involving $\mathrm{H}_{2} \mathrm{O}_{2}$ was proposed.

Conclusion. Any effect that initiates the formation of methemoglobin leads to an increase in the peroxidase activity of hemoglobin due to the involvement of the latter in the pseudoperoxidase cycle and the formation of toxic reactive globin radicals. The high

2021 O. I. Dotsenko, G. V. Taradina, \& A. M. Mischenko. Published by the Ivan Franko National University of Lviv on behalf of Біологічні Студії / Studia Biologica. This is an Open Access article distributed under the terms of the Creative Commons Attribution 4.0 License which permits unrestricted reuse, distribution, and reproduction in any medium, provided the original work is properly cited.

ISSN 1996-4536 (print) • ISSN 2311-0783 (on-line) • Біологічні Студії / Studia Biologica • 2021 • Том 15 / № 4 • С. 3-16 
content of oxyhemoglobin in the cell, observed under vibrations within the frequency range of $16-32 \mathrm{~Hz}$ with an amplitude of $0.9 \pm 0.08 \mathrm{~mm}$, can prevent its oxidation and involvement in the pseudoperoxidase cycle.

Keywords: ligand forms of hemoglobin, enzymatic kinetics, kinetic constants, pseudoperoxidase cycle, heme, hypoxia, p-phenylenediamine

\section{INTRODUCTION}

Hemoglobin is one of the most studied animal proteins, the function of which is related to oxygen transport. However, additional functions of hemoglobin are known as well (Paco et al., 2009; Kosmachevskaya \& Topunov, 2018). Some of them have physiological significance and evolved to increase the adaptive potential of cells, others are the result of chemical and thermodynamic properties of the protein (Kosmachevskaya \& Topunov, 2018).

Hemoproteins are of interest for researchers who study structure-activity relationship, firstly, because the active site, iron porphyrin, is the same for all hemoproteins and secondly, because additional activity could arise from the structural and conformational properties of this protein. Thus, peroxidase activity of hemoglobin can be used to test for any structural changes that may have occurred in the hemoglobin molecule as a result of chemical modifications. The consequence of these changes may be a change in the oxidative activity of modified hemoglobin (Everse et al., 1994). Although $\mathrm{H}_{2} \mathrm{O}_{2}$ binds directly to heme iron, the substrate can donate its electrons to the edge of the heme or in some cases even interact with the protein part of the enzyme (similar to peroxidases), because some substrates are too bulky to penetrate the heme pocket (Everse et al., 1994). According to the abovesaid, any changes that occur inside the chemical or structural heme environment can possibly lead to changes in oxidation rate of its substrate.

The dissociation of hemoglobin into monomers or the formation of crosslinks due to the oxidation of amino acid residues can lead to an increase in peroxidase activity of hemoglobin. Reeder et al. demonstrated (Reeder, 2010; Reeder, 2017) that the formation of a covalent bond between heme and protein fragment for $\mathrm{Hb}$ or $\mathrm{Mb}$ treated with hydrogen peroxide increases peroxidase activity and toxicity of the latter.

It is accepted that met- and oxyhemoglobin belong to pseudoperoxidases group, heme-containing proteins that perform essential functions in cells and were not originally intended to interact with $\mathrm{H}_{2} \mathrm{O}_{2}$, but could be converted into peroxidases as a result of environmental changes and development of oxidative stress (Vlasova, 2018). When interacting with $\mathrm{H}_{2} \mathrm{O}_{2}$, these compounds give hypervalent ferryl heme iron (FelV = O) and globin tyrosyl radical (Svistunenko et al., 2002; Witting et al., 2002; Reeder, 2017; Huo et al., 2021), which is able to initiate further oxidation reactions (Dotsenko et al., 2018).

However, there is evidence that globins are true peroxidases with a specific biological role (Reeder, 2017). It was found that in the presence of peroxide and ascorbate or urate, oxyhemoglobin functions as a true enzymatic peroxidase (Cooper et al., 2008; Cooper et al., 2013). Peroxidase activity of oxyhemoglobin is low (this value is 5 times higher for methemoglobin compared to oxyhemoglobin). A high content of oxyhemoglobin promotes the consumption of hydrogen peroxide in large quantities, thereby preventing the oxidation of hemoglobin and the entry of $\mathrm{H}_{2} \mathrm{O}_{2}$ into the pseudoperoxidase cycle. The consequence of these processes is the inhibition of toxicity of ferryl forms of hemoglobin (Widmer et al., 2010; Huo et al., 2021).

ISSN 1996-4536 (print) • ISSN 2311-0783 (on-line) • Біологічні Студії / Studia Biologica • 2021 • Том 15 / № 4 • С. 3-16 
Peroxidase activity of hemoglobin remains obscure, for example there is a lack of research data on physiological role of hemoglobins peroxidase activity and its role during hypoxia. So far, it has been accepted that mechanical stress could affect the properties of biomolecules and cells (Shatalov, 2012; Dotsenko \& Troshchynskaya, 2014; Bunkin et al., 2020). Under conditions of vibration, it is convenient to simulate both oxidative stress and hypoxia by changing the parameters and duration of vibrations. In parallel, it is possible to study the effect of low-frequency vibrations on the state of human erythrocytes. Testing for hemoglobin peroxidase activity can be useful for understanding the state of hemoglobin in cells and their viability.

The aim of the study was to examine changes in peroxidase activity of human erythrocytes under the conditions of low-frequency vibrations, study the kinetics and discover the parameters of peroxidase reaction involving hemoglobin. We have proven that the erythrocyte peroxidase activity depends on the ratio of the hemoglobin ligand forms content in erythrocytes when the oxygen content in the cell surface changes.

\section{MATERIALS AND METHODS}

The protocol of the experimental part was in compliance with the principles of biological ethics and was agreed upon with the Local Ethics Committee of the Vasyl' Stus Donetsk National University, Faculty of Chemistry, Biology and Biotechnology (Vinnytsia, Ukraine). The meeting of Bioethics Commission No 2 of January 11, 2021.

Peripheral blood of healthy female donors of approximately the same age (45 \pm 5.5 years) was used in the study. Erythrocytes were separated from plasma by centrifugation and washed three times with Na-phosphate buffer $(0.015 \mathrm{~mol}, \mathrm{pH} 7.4)$ (buffer solution 1) containing $0.15 \mathrm{~mol} \mathrm{NaCl}$. In the obtained erythrocyte paste, the total hemoglobin content was determined by the hemoglobin cyanide unified method using a standard kit.

The resulting erythrocyte paste was introduced into the medium of the same buffer solution. The hemoglobin content in the test suspensions was at the level of $1.4 \pm 0.08 \mathrm{mg} / \mathrm{mL}$. The suspensions were subjected to low-frequency vibrations for $3 \mathrm{~h}$ within the frequency range from 8 to $32 \mathrm{~Hz}$ at room temperature. The vibration frequency varied with step of $4 \mathrm{~Hz}$. The vibration amplitude was maintained at $0.5 \pm 0.04$ and $0.9 \pm 0.08 \mathrm{~mm}$. The vibrations were generated using a vibrating stand which consisted of a sinusoidal low-frequency signal generator, an amplifier and a vibrator that oscillates in the vertical plane with a given frequency and amplitude. The experimental cuvette filled with the erythrocyte suspension was fixed vertically tightly on the moving part of the vibrator (in this case, mechanical vibrations are transmitted to the experimental cuvette with a slight loss of power).

The peroxidase activity was determined in the fresh lysates of cells. Erythrocyte lysate was obtained by lysis of cells in $0.01 \mathrm{M} \mathrm{Na-phosphate} \mathrm{buffer}(\mathrm{pH} \mathrm{7.4)}$ in cold for $10 \mathrm{~min}$.

As a control, erythrocytes contained in buffer solution 1 and not exposed to vibration were used. The three-hour effect of the incubation medium on the peroxidase activity of hemoglobin was additionally tested.

Determination of hemoglobin peroxidase activity. All spectrophotometric studies were performed on SPEKOL ${ }^{\circledR} 1500$ UV/Vis spectrophotometer at room temperature.

ISSN 1996-4536 (print) • ISSN 2311-0783 (on-line) • Біологічні Студії / Studia Biologica • 2021 • Том 15 / № 4 • С. 3-16 
The concentration of hydrogen peroxide in the initial solution was measured using the value of the extinction coefficient $\varepsilon_{240}=43.6 \mathrm{M}^{-1} \times \mathrm{CM}^{-1}$. A stock solution of $p$-phenylenediamine (PDA) was prepared by dissolving the exact portion in buffer solution 1 .

The level of PDA activity was determined spectrophotometrically, recording the oxidation of PDA at $485 \mathrm{~nm}$ for $3 \mathrm{~min}$. To determine the activity, $0.1 \mathrm{~mL}$ of erythrocyte lysate was added to $2 \mathrm{~mL}$ of $20 \mathrm{mM}$ p-phenylenediamine solution $(\mathrm{pH} \mathrm{7.4)}$. The reaction was started by the introduction of $0.1 \mathrm{~mL}$ of hydrogen peroxide. The concentration of hydrogen peroxide in the reaction mixture was $2 \mathrm{mM}$. All measurements were performed at $37^{\circ} \mathrm{C}$. The initial rate of reaction $\left(v_{0}\right)$ was determined from the initial linear sections of the kinetic dependency. The enzymatic activity was calculated using a molar extinction coefficient $1.545 \times 10^{3} \mathrm{M}^{-1} \mathrm{CM}^{-1}$ and expressed in $\mathrm{mM}$ of phenylenediamine oxidized in $1 \mathrm{~min}$.

Calculation of catalytic constants. The rate constants in the oxidation reaction of p-phenylenediamine, Michaelis constants for both substrates were determined based on stationary kinetics. For this purpose, the concentrations of both substrates were varied: in the range of 4.5 to $23 \mathrm{mM}$ for $p$-phenylenediamine and 1.5 to $3.5 \mathrm{mM} \mathrm{for} \mathrm{H}_{2} \mathrm{O}_{2}$. The concentration of $\mathrm{H}_{2} \mathrm{O}_{2}$ was maintained at $2 \mathrm{mM}$ during the variation of $p$-phenylenediamine. The concentration of $p$-phenylenediamine was maintained at $20 \mathrm{mM}$ during the variation of $\mathrm{H}_{2} \mathrm{O}_{2}$. The concentration of hemoglobin in the sample was $0.15 \pm 0.013 \mathrm{mg} / \mathrm{mL}$. The initial reaction rate was recorded as described above. The catalytic constant and Michaelis constants for substrates were calculated from the equation for the ping-pong type peroxidase mechanism defined by Dunford:

$$
\frac{E_{0}}{v}=\frac{1}{k_{\text {cat }}} \cdot \frac{K_{m \mathrm{H}_{2} \mathrm{O}_{2}}}{\left[\mathrm{H}_{2} \mathrm{O}_{2}\right]}+\left(\frac{1}{k_{\text {cat }}} \cdot\left(1+\frac{K_{m P D A}}{\mathrm{PDA}}\right)\right),
$$

where $[E]_{0}$ is the concentration of hemoglobin in the sample; $k_{\text {cat }}$ - catalytic constant, corresponding to the monomolecular rate-limiting step; $K_{\mathrm{mH}_{2} \mathrm{O}_{2}}$ - Michaelis constant for hydrogen peroxide; $K_{m P D A}$ is the Michaelis constant for the $p$-phenylenediamine donor substrate. The kinetic parameters for the peroxidase reaction $\left(k_{\text {cat }}, K_{m H_{2} \mathrm{O}_{2}}, K_{m P D A}\right)$ were determined before the start of the experiment and after $2 \mathrm{~h}$ of exposure to buffer medium and vibration using the gradient descent method.

Determination of the hemoglobin ligand forms content. The resulting hemolysate was centrifuged to precipitate membrane-bound hemoglobin. The absorption spectra of the cytoplasmic fraction of erythrocyte hemoglobin were recorded in the wavelength range $500-700 \mathrm{~nm}$ in cuvettes with a thickness of $1 \mathrm{~mm}$.

The total hemoglobin content in the cytoplasmic fraction of hemoglobin was determined by absorption at a wavelength of $523 \mathrm{~nm}$ using an extinction coefficient of $7120 \mathrm{M} / \mathrm{cm}$ (Ratanasopa et al., 2015).

To determine the content of ligand forms of hemoglobin, absorption at 540, 560, 576 and $630 \mathrm{~nm}$ (Dotsenko et al., 2020) was used. The content of ligand forms of hemoglobin (in M) was calculated using the equations given in (Dotsenko et al., 2020). The content of each form was expressed as a percentage of the total hemoglobin content in the cytoplasmic fraction.

All experiments were performed in triplicate $(n=3)$, and their results were analyzed in Statistica 8.0 (StatSoft Inc., USA). Experimental data is presented as $x \pm m$ ( $x$ is the average, $m$ is the relative error). Differences between kinetic parameters in the control

ISSN 1996-4536 (print) • ISSN 2311-0783 (on-line) • Біологічні Студії / Studia Biologica • 2021 • Том 15 / № 4 • С. 3-16 
and experimental samples were determined using the Wilcoxon T-test. The critical level of significance in testing of statistical hypotheses was taken as equal to $p<0.05$. Threedimensional scattering plots were used to present the obtained experimental data and to identify the relationships between the studied parameters. Based on the network of starting points, the surface was built by the method of inversely weighted distances. To construct the distribution curves of the ligand forms of hemoglobin, we used data approximation by the method of least squares according to the polynomial regression equation of the 6th degree.

\section{RESULTS AND DISCUSSION}

Analysis of changes in erythrocyte hemoglobin peroxidase activity under vibration conditions. In fig. 1, 2 the change in the erythrocyte hemoglobin peroxidase activity depending on the frequency, amplitude and time of vibration are shown. At the beginning of the experiment, the activity was in the range of $0.22-0.4 \mathrm{mM} / \mathrm{min} \times \mathrm{g} \mathrm{Hb}$, an according to the figure is highly dependent on the ratio of oxyHb/metHb in cells. Under the action of vibrations within the frequency range of $8-32 \mathrm{~Hz}$ with an amplitude of $0.5 \pm 0.04 \mathrm{~mm}$ peroxidase activity dose-dependently increased and after 3 hours of exposure exceeded the initial level by 1.5-1.8 times (Fig. 1). When vibrating in the frequency range of $16-28 \mathrm{~Hz}$ with an amplitude of $0.9 \pm 0.08 \mathrm{~mm}$ peroxidase activity increased more than twice after 2 hours of exposure (Fig. 2).

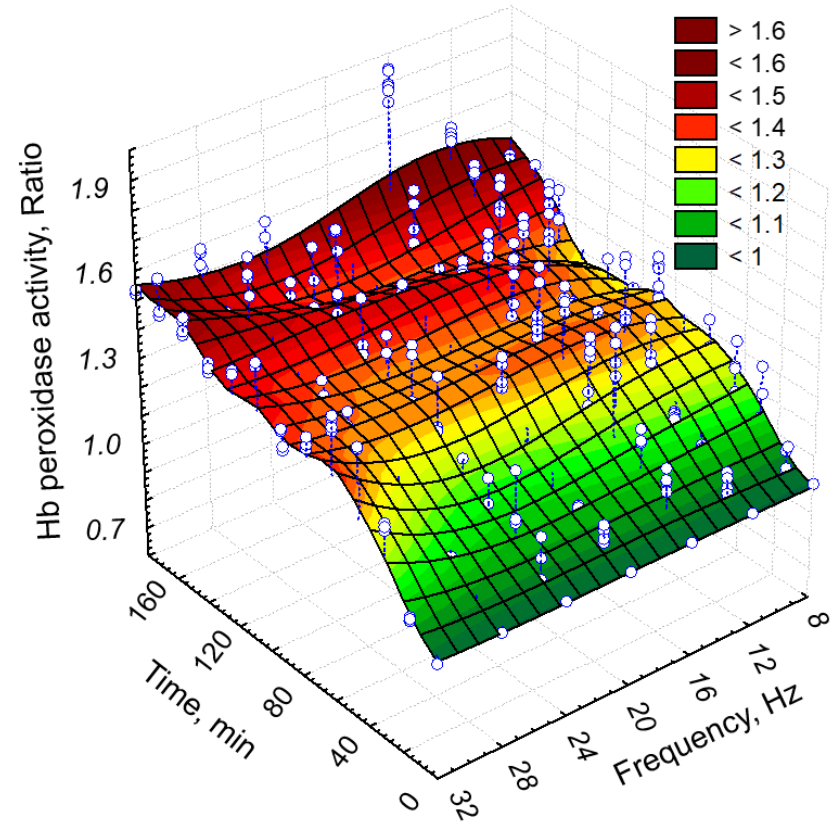

Fig. 1. Peroxidase activity of erythrocyte lysate under the conditions of vibration in the frequency range of 8-32 Hz with amplitudes of $0.5 \pm 0.04 \mathrm{~mm}$ depending on the incubation time of cells. $\mathrm{N}$ (the number of points on the surface) $=108, n=3$

Рис. 1. Пероксидазна активність гемолізату еритроцитів в умовах вібраційного впливу в інтервалі частот 8-32 Гц з амплітудами 0,5 £ 0,04 мм залежно від часу інкубування клітин. N (кількість точок на поверхні) $=108, \mathrm{n}=3$ 


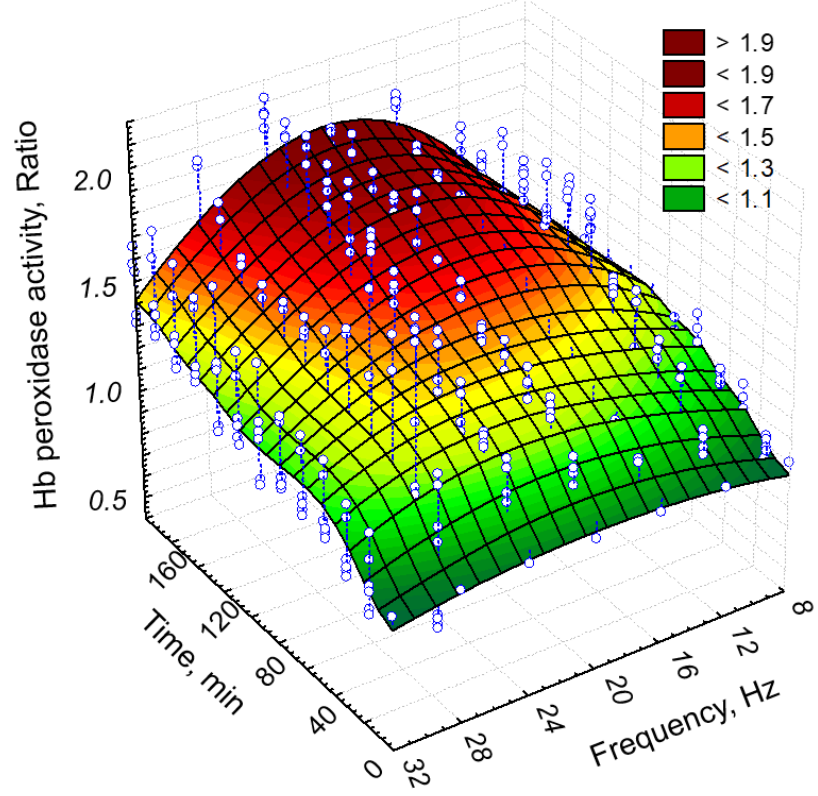

Fig. 2. Peroxidase activity of erythrocyte lysate under the conditions of vibration in the frequency range of 8-32 $\mathrm{Hz}$ with amplitudes of $0.9 \pm 0.08 \mathrm{~mm}$ depending on the incubation time of cells. $\mathrm{N}$ (the number of points on the surface) $=108, n=3$

Рис. 2. Пероксидазна активність гемолізату еритроцитів в умовах вібраційного впливу в інтервалі частот 8-32 Гц з амплітудами 0,9 \pm 0,08 мм залежно від часу інкубування клітин. N (кількість точок на поверхні) $=108, \mathrm{n}=3$

Analysis of kinetic parameters of peroxidase reaction. To determine the kinetic constants of peroxidase reaction, graphs of the reaction rates dependency on the concentration of $\mathrm{H}_{2} \mathrm{O}_{2}$ and PDA in double inverse coordinates (Lineweaver-Burk plot) at a fixed concentration of another substrate were constructed. In these coordinates, the dependency is linear.

The obtained values of peroxidase reaction constants for hemoglobin of erythrocytes that were not exposed to vibrations are shown in Table 1. Given rather high values of Michaelis constants for substrates, it can be argued that, unlike heme peroxidases in plants, mammalian $\mathrm{Hb}$ peroxidase activity has not evolved to remove peroxide from biological solutions. For hemoglobin, the rate of $\mathrm{H}_{2} \mathrm{O}_{2}$ reduction is slower than PDA oxidation, which means that the reaction with $\mathrm{H}_{2} \mathrm{O}_{2}$ is a rate-limited step. Besides, a fairly wide range of changes in the values of the constants indicates that the peroxidase reaction involves both oxy- $(\mathrm{oxyHb})$ and methemoglobin (metHb) and the found constants do not characterize a particular form of hemoglobin.

When interacting with $\mathrm{H}_{2} \mathrm{O}_{2}$, OxyHb can form a compound II peroxidase cycle, in which heme iron is present in the oxoferryl form (Reeder, 2017; Vlasova, 2018):

$$
\begin{aligned}
& \mathrm{P}-\mathrm{Fe}^{2+}+\mathrm{H}_{2} \mathrm{O}_{2} \rightarrow \mathrm{P}-\left[\mathrm{Fe}^{4+}=\mathrm{O}\right]+\mathrm{H}_{2} \mathrm{O} . \\
& \text { Compound II }
\end{aligned}
$$

OxyHb is easily oxidized to methemoglobin (Liu et al., 2020; Huo et al., 2021):

$$
\mathrm{P}-\mathrm{Fe}^{2+} \cdot \mathrm{O}_{2}+\mathrm{H}_{2} \mathrm{O}_{2} \rightarrow \mathrm{P}-\mathrm{Fe}^{3+}+\mathrm{O}_{2}+\mathrm{H}_{2} \mathrm{O} \text {. }
$$

ISSN 1996-4536 (print) • ISSN 2311-0783 (on-line) • Біологічні Студії / Studia Biologica • 2021 • Том 15 / № 4 • С. 3-16 
Interaction between hydrogen peroxide and methemoglobin leads to the formation of compound I, which is most likely an oxoferryl porphyrin- $p$-cation radical. Compound I immediately oxidizes aminoacid residues (Tyr, Trp, His), which are located near heme, with the formation of radicals based on protein and oxoferrylheme (Vlasova, 2018).

$$
\begin{aligned}
& \mathrm{P}-\mathrm{Fe}^{3+}+\mathrm{H}_{2} \mathrm{O}_{2} \rightarrow{ }^{+} \mathrm{P} \cdot-\left[\mathrm{Fe}^{4+}=\mathrm{O}\right]+\mathrm{H}_{2} \mathrm{O}, \\
& \text { Compound I } \\
& { }^{+} \mathrm{P}^{\bullet}-\left[\mathrm{Fe}^{4+}=\mathrm{O}\right] \rightarrow \mathrm{P}^{\bullet}-\left[\mathrm{Fe}^{3+}=\mathrm{O}\right]+\mathrm{P}-\left[\mathrm{Fe}^{4+}=\mathrm{O}\right], \\
& \text { Compound II } \\
& \mathrm{P}-\left[\mathrm{Fe}^{4+}=\mathrm{O}\right]+\mathrm{AH}_{2} \rightarrow \mathrm{P}-\mathrm{Fe}^{3+}+\mathrm{AH}^{\bullet}, \\
& \mathrm{P}^{\bullet}-\left[\mathrm{Fe}^{3+}=\mathrm{O}\right]+\mathrm{AH}_{2} \rightarrow \mathrm{P}-\mathrm{Fe}^{3+}+\mathrm{AH}^{\bullet},
\end{aligned}
$$

Peroxidase substrates can be oxidized in two ways: by direct electron transfer between the reducing agent and heme, if heme in hydrophobic pocket is available for the substrate (equation 5); or by a tyrosyl radical on the surface of the protein (equation 6), or in two ways simultaneously. Mediation of substrate oxidation by tyrosyl radicals accelerates heme recovery (Reeder, 2010; Vlasova, 2018). Obviously, these processes are present in erythrocytes with ascorbate as a natural substrate. The consequence of the formation of tyrosyl radicals is the formation of crosslinks and aggregation of protein, which reduces the oxidative potential of peroxidase (Vlasova, 2018).

Analysis of the obtained data showed that both incubation of cells in buffer solution and vibration creates conditions for non-competitive activation of hemoglobin peroxidase activity. Incubation of erythrocytes in Na-phosphate medium for $2 \mathrm{~h}$ does not change the catalytic constant of the reaction, but leads to a significant $K_{m H_{2} \mathrm{O}_{2}}$ increase and $K_{m P D A}$ decrease (Table 1 ). Thus, the rate of the peroxidase process increases due to the increase in affinity for PDA. In this case, the high-affinity pathway involves electron transfer through the protein, utilizing a tyrosine as a redox-active center. Mediation of a substrate oxidation by tyrosyl radicals accelerates heme reduction but decreases the oxidative potential of peroxidase (Svistunenko et al., 2002; Vlasova, 2018).

Table 1. The effect of incubation medium on the steady-state kinetic constants of peroxidase reaction involving hemoglobin

Таблиця 1. Вплив середовища інкубування на стаціонарні кінетичні константи пероксидазної реакції за участю гемоглобіну

\begin{tabular}{|c|c|c|c|c|c|}
\hline \multicolumn{3}{|c|}{ Fresh erythrocytes } & \multicolumn{3}{c}{ Erythrocytes incubated in the medium for 2 hours } \\
\hline$k_{\text {cat }}, 1 / \mathrm{min}$ & $K_{m \mathrm{H}_{2} \mathrm{O}_{2}}, \mathrm{mM}$ & $K_{m \mathrm{PDA}}, \mathrm{mM}$ & $k_{\text {cat }}, 1 / \mathrm{min}$ & $K_{m \mathrm{H}_{2} \mathrm{O}_{2}}, \mathrm{mM}$ & $K_{m \mathrm{PDA}}, \mathrm{mM}$ \\
\hline $33.7 \pm 5.01$ & $105 \pm 12.7$ & $83.74 \pm 11.8$ & $30.8 \pm 4.8$ & $136.9 \pm 10.6^{*}$ & $52.43 \pm 10.4^{*}$ \\
\hline
\end{tabular}

Comment: * - the differences are significant at $p<0.05$

Примітка: * - різниця достовірна при $\mathrm{p}<0,05$

Low-frequency vibration leads to $k_{\text {cat }}$ growth, except for exposure with an $8 \mathrm{~Hz}$ frequency and $0.5 \pm 0.04 \mathrm{~mm}$ amplitude (Table 2). Vibration exposure (frequency range 8-16 Hz, amplitude $0.5 \pm 0.04 \mathrm{~mm}$ ) causes a significant $K_{\mathrm{mH}_{2} \mathrm{O}_{2}}$ increase, which indicates

ISSN 1996-4536 (print) • ISSN 2311-0783 (on-line) • Біологічні Студії / Studia Biologica • 2021 • Том 15 / № 4 • С. 3-16 
certain structural changes associated with the constrained access of $\mathrm{H}_{2} \mathrm{O}_{2}$ to heme. Peroxidases are characterized by the specific location of amino acids in the active center for effective coordination and use of $\mathrm{H}_{2} \mathrm{O}_{2}$ (Vlasova, 2018). Binding of $\mathrm{H}_{2} \mathrm{O}_{2}$ causes immediate oxidation of protein amino acids that are close to the active center (most commonly tyrosine, tryptophan, or histidine). In addition, protein-based tyrosyl radicals are alternative reactive intermediates capable of initiating oxidation of hemoglobin itself.

Table 2. Steady-state kinetic constants for peroxidase activity of hemoglobin

Таблиця 2. Стаціонарні кінетичні константи пероксидазної активності гемоглобіну

\begin{tabular}{c|ccc|c|c|c}
\hline & \multicolumn{5}{|c}{ Vibration amplitude, $\mathrm{mm}$} \\
$\begin{array}{c}\text { Frequency, } \\
\mathrm{Hz}\end{array}$ & \multicolumn{3}{|c|}{$0.5 \pm 0.04$} & & & \\
& $k_{\text {cat }}, 1 / \mathrm{min}$ & $K_{\mathrm{mH}_{2} \mathrm{O}_{2}}, \mathrm{mM}$ & $K_{\mathrm{mPA}}, \mathrm{mM}$ & $k_{\text {cat }}, 1 / \mathrm{min}$ & $K_{m \mathrm{H}_{2} \mathrm{O}_{2}}, \mathrm{mM}$ & $K_{m \mathrm{PDA}}, \mathrm{mM}$ \\
\hline $\mathbf{8}$ & $25 \pm 5.5$ & $130 \pm 9.2^{*}$ & $40 \pm 8.6^{*}$ & $42.5 \pm 5.5$ & $151.1 \pm 9.6^{*}$ & $80.7 \pm 4.5$ \\
\hline $\mathbf{1 6}$ & $50.4 \pm 6.2^{*}$ & $151.2 \pm 10.1^{*}$ & $80.8 \pm 6.3$ & $41.9 \pm 4.6$ & $123.6 \pm 8.1$ & $62.3 \pm 5.5^{*}$ \\
\hline $\mathbf{2 4}$ & $45.9 \pm 5.5^{*}$ & $128.7 \pm 6.7^{*}$ & $65.8 \pm 5.5$ & $43.2 \pm 6.4$ & $121.6 \pm 6.1$ & $60.5 \pm 5.1^{*}$ \\
\hline $\mathbf{3 2}$ & $39.8 \pm 6.5$ & $119.5 \pm 7.1$ & $75.0 \pm 6.4$ & $40.2 \pm 6.6$ & $120.5 \pm 7.3$ & $62 \pm 5.0^{*}$ \\
\hline
\end{tabular}

Comment: * - the differences are significant at $p<0.05$

Примітка: * - різниця достовірна при $р<0.05$

Exposure in the frequency range of $24-32 \mathrm{~Hz}$ (amplitude $0.5 \pm 0.04 \mathrm{~mm}$ ) and 16-32 $\mathrm{Hz}$ amplitude $0.9 \pm 0.08 \mathrm{~mm}$ ) leads to a smaller $K_{m \mathrm{H}_{2} \mathrm{O}_{2}}$ increase and $K_{m \text { PDA }}$ decrease. Under these conditions, these kinetic parameters remain at approximately the same level.

The erythrocyte incubation medium contains some amount of dissolved oxygen contained in nanobubbles stabilized by adsorbed $\mathrm{Na}^{+}$ions (Bunkin \& Bunkin, 2016; Uchida et al., 2016). It is assumed that the target of vibration is nanobubbles of dissolved air, which are retained on the surface of erythrocytes due to Coulomb interactions and are able to coagulate and increase in size under the action of vibration (Bunkin et al., 2011). It is thought that oxygen bubbles are involved in the processes of oxygenation deoxygenation with the participation of hemoglobin (Shatalov et al., 2012). Shaking of the solutions leads to the collapse of the bubbles and release of energy. However, the consequence of further growth of microbubbles is degassing of the liquid as a result of the multiplied force of Archimedes that pushes the microbubbles to the surface of the solution (Shatalov et al., 2012). Thus, depending on the parameters and duration of vibration, it is possible to simulate both an increase in the concentration of oxygen in the surface of erythrocytes and a decrease as a result of degassing of the liquid.

Given the mechanism of action of vibration described above, we hypothesized that the described changes in kinetic parameters are associated with a different ratio of $\mathrm{oxyHb} / \mathrm{metHb}$ hemoglobin in the cytoplasmic fraction of cells. Fig. 3-6 show the change of ligand forms of hemoglobin in erythrocytes incubated for $3 \mathrm{~h}$ in Na-phosphate buffer and under the conditions of vibration.

In the absence of vibration, the level of oxyHb decreased rapidly during 20 min of the experiment and turned into met- and deoxy-form (Fig. 3). Under the conditions of

ISSN 1996-4536 (print) • ISSN 2311-0783 (on-line) • Біологічні Студії / Studia Biologica • 2021 • Том 15 / № 4 • С. 3-16 
low vibration intensity, the decrease in oxyHb content occurred 60-80 min after the beginning of the experiment (Fig. 4). Under the action of vibration in the frequency range of $16-32 \mathrm{~Hz}$ with an amplitude of $0.9 \pm 0.08 \mathrm{~mm}$, oxyHb content remained at the initial level for 90 min of the experiment and then decreased by $4-5 \%$ (Figs. 5, 6). The content of metHb in erythrocytes not exposed to vibration increased and reached the level of $15.7 \pm 1.26 \%$ (Fig. 3), when vibrating with a $16 \mathrm{~Hz}$ frequency, the content of methemoglobin in erythrocytes was lower (Fig. 4, 5), and when vibrating with a frequency of $32 \mathrm{~Hz}$, the amplitude of $0.9 \pm 0.08 \mathrm{~mm}$ was at the level of $11.6 \pm 0.7 \%$ (Fig. 6).

Fig. 3. The distribution of ligand forms in the composition of cytoplasmic fractions of erythrocyte hemoglobin incubated in the medium of $\mathrm{Na}^{+}$-phosphate buffer for $3 \mathrm{~h}$. Each point represents $x \pm m$ for $n=5$

Рис. 3. Розподіл лігандних форм гемоглобіну в цитоплазматичній фракції еритроцитів, що інкубували впродовж 3-х годин у середовищі $\mathrm{Na}^{+}-$ фросфатного буфера. Кожна точка представлена як $\mathrm{x} \pm \mathrm{m}$ для $\mathrm{n}=5$

Fig. 4. The distribution of ligand forms in the composition of cytoplasmic fractions of erythrocyte hemoglobin under the conditions of vibration with the frequency of $16 \mathrm{~Hz}$ and amplitude of $0.5 \pm 0.04 \mathrm{~mm}$. Each point represents $x \pm m$ for $n=5$

Рис. 4. Розподіл лігандних фрорм гемоглобіну в цитоплазматичній фракції еритроцитів, що перебували в умовах вібраційного впливу з частотою 16 Гц, амплітудою 0,5 \pm 0,04 mm. Кожна точка представлена як $\mathrm{x} \pm \mathrm{m}$ для $\mathrm{n}=5$

Fig. 5. The distribution of ligand forms in the composition of cytoplasmic fractions of erythrocyte hemoglobin under the conditions of vibration with the frequency of $16 \mathrm{~Hz}$ and amplitude of $0.9 \pm 0.08 \mathrm{~mm}$. Each point represents $x \pm m$ for $n=5$

Рис. 5. Розподіл лігандних форм гемоглобіну в цитоплазматичній фракції еритроцитів, що перебували в умовах вібраційного впливу з частотою 16 Гц, амплітудою 0,9 \pm 0,08 mm. Кожна точка представлена як $\mathrm{x} \pm \mathrm{m}$ для $\mathrm{n}=5$
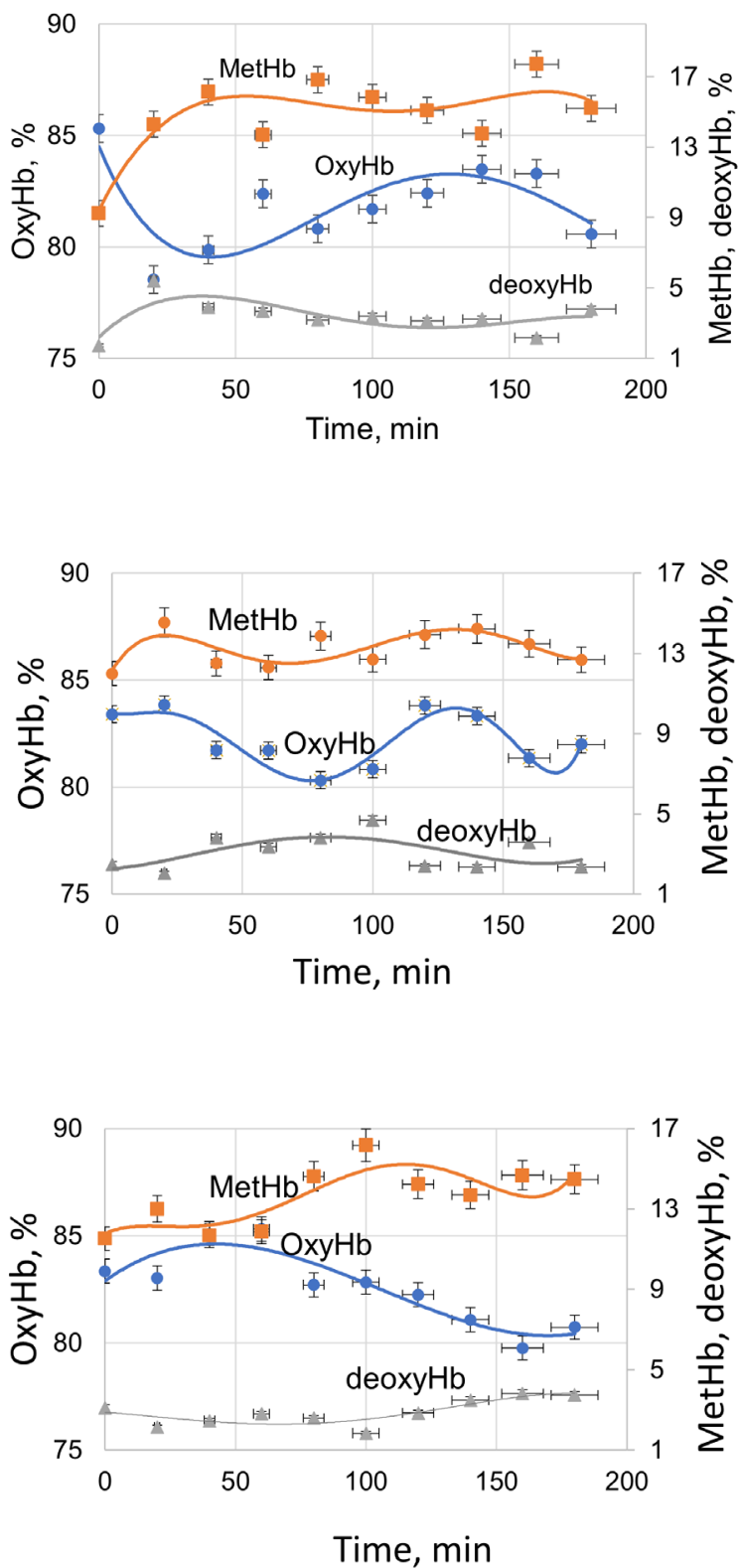


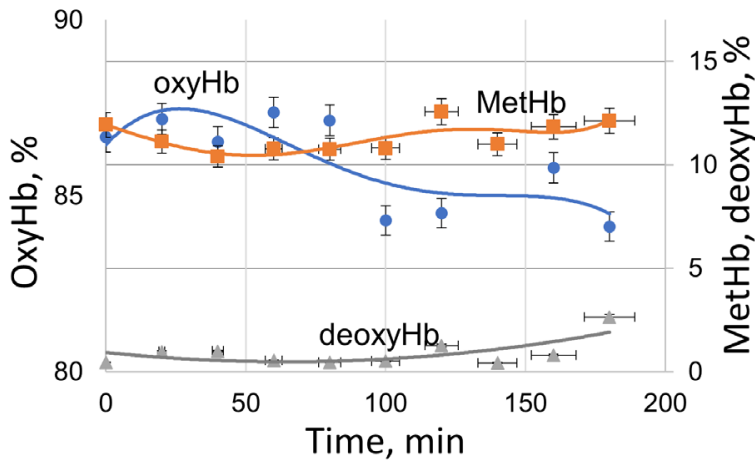

Fig. 6. The distribution of ligand forms in the composition of cytoplasmic fractions of erythrocyte hemoglobin under the conditions of vibration with the frequency $32 \mathrm{~Hz}$, and amplitude of $0.9 \pm 0.08 \mathrm{~mm}$. Each point represents $\mathrm{x} \pm \mathrm{m}$ for $\mathrm{n}=5$

Рис. 6. Розподіл лігандних фоорм гемоглобіну в цитоплазматичній фракції еритроцитів, що перебували в умовах вібраційного впливу з частотою 32 Гц, амплітудою 0,9 $\pm 0,08 \mathrm{~mm}$. Кожна точка представлена як $\mathrm{x} \pm \mathrm{m}$ для $\mathrm{n}=5$

In this study, we measured kinetic parameters after $2 \mathrm{~h}$ of exposure, hence, in our opinion, it is very important to understand the nature of changes in oxyHb/metHb that occur in cells. Huo et al. (2021), who used tyrosine as a substrate, showed that under the conditions of high content of oxyhemoglobin, the latter retains peroxidase properties and oxidation of the substrate occurs mainly in the pocket of heme (by reaction 6). In addition, the authors argue that $\mathrm{P}-\mathrm{Fe}^{2+}$ participation in the peroxidase cycle inhibits the pseudoperoxidase cycle. A high concentration of oxyHb causes a fairly high rate of peroxidase process. The appearance of metHb, or its addition to the reaction mixture (Huo et al., 2021) increases the speed of the peroxidase process by connecting a pseudoperoxidase cycle, which attracts radical forms of protein in the processes of electron transfer from substrate to heme (Reeder, 2010). Our data on the change in peroxidase activity over time (Fig. 2) correlate well with the obtained dependence of the change in metHb content in cells (Fig. 5). The high level of oxygenation of hemoglobin for $100 \mathrm{~min}$ in the conditions of vibration in the frequency range of $16-32 \mathrm{~Hz}$ with an amplitude of $0.9 \pm 0.08 \mathrm{~mm}$ allows to keep hemoglobin in a functional state avoiding its damage.

Due to the tendency of oxyHb to autooxidation, the formation of metHb is unavoidable. However, reducing the intensity of this process or increasing the level of oxygenation will reduce the content of highly reactive compounds that occur in the pseudoperoxidase cycle.

Thus, hemoglobin cannot avoid certain reactivity to peroxide if it wants to retain its ability to bind oxygen. Further interaction with ascorbate becomes a requirement to prevent damage after peroxide has inevitably reacted with heme (Cooper et al., 2008). Completion of the peroxidase cycle is a protective mechanism that sacrifices ascorbate or urate to prevent damage to heme or other biological targets such as lipids. During hypoxia, the oxidized form of $\mathrm{P}-\mathrm{Fe}^{2+}$ participates in the pseudoperoxidase cycle, which leads to lipid peroxidation, protein modification and accelerates apoptotic processes.

\section{CONCLUSION}

Any effect that initiates the formation of methemoglobin leads to an increase in peroxidase activity of hemoglobin due to the involvement of the latter in the pseudoperoxidase cycle and the formation of toxic reactive globin radicals. The high content of 
oxyhemoglobin in the cell, that is observed in the conditions of vibration in the frequency range of $16-32 \mathrm{~Hz}$ with an amplitude of $0.9 \pm 0.08 \mathrm{~mm}$, can prevent its oxidation and entry into the pseudoperoxidase cycle.

\section{COMPLIANCE WITH ETHICAL STANDARDS}

Conflicts of Interest: The authors declare that the research was conducted in the absence of any commercial or financial relationships that could be construed as a potential conflict of interest.

Human Rights: This article does not contain any studies with human subjects performed by any of the authors.

\section{AUTHOR CONTRIBUTIONS}

Conceptualization, [O.I.D.]; methodology, [O.I.D.]; validation, [O.I.D.; G.V.T.]; formal analysis, [O.I.D; G.V.T.].; investigation, [O.I.D.; G.V.T.; A.M.M.]; resources, [O.I.D.; G.V.T.; A.M.M.]; data curation, [O.I.D.; G.V.T.; A.M.M.]; writing - original draft preparation, [O.I.D.]; writing - review and editing, [O.I.D.; G.V.T.; A.M.M.]; visualization, [O.I.D.] supervision, [O.I.D.]; project administration, [O.I.D.]; funding acquisition, [-].

\section{REFERENCES}

Bunkin, N. F., Ninham, B. W., Ignatiev, P. S., Kozlov, V. A., Shkirin, A. V., \& Starosvetskij, A. V. (2011). Long-living nanobubbles of dissolved gas in aqueous solutions of salts and erythrocyte suspensions. Journal of Biophotonics, 4(3), 150-164. doi:10.1002/jbio.201000093

Crossref $\bullet$ PubMed $\bullet$ Google Scholar

Bunkin, N. F., \& Bunkin, F. V. (2016). Bubston structure of water and electrolyte water solutions. Uspekhi Fizicheskih Nauk, 186(9), 933-952. doi:10.3367/ufnr.2016.05.037796 Crossref $\bullet$ Google Scholar

Bunkin, N. F., Bunkin, N. F., Shkirin, A. V., Shkirin, A. V., Ninham, B.W., Chirikov, S. N., Chaikov, L. L., Penkov, N. V., Kozlov, V. A., Kozlov, V. A., \& Gudkov S. V. (2020). Shakinginduced aggregation and flotation in immunoglobulin dispersions: differences between water and water-ethanol mixtures. ACS Omega, 5, 14689-14701. doi:10.1021/acsomega.0c01444 Crossref • PubMed • PMC • Google Scholar

Cooper, C. E., Silaghi-Dumitrescu, R., Rukengwa, M., Alayash, A. I., \& Buehler P. W. (2008). Peroxidase activity of hemoglobin towards ascorbate and urate: A synergistic protective strategy against toxicity of Hemoglobin-Based Oxygen Carriers (HBOC). Biochimica et Biophysica Acta - Proteins and Proteomics, 1784(10), 1415-1420. doi:10.1016/j.bbapap.2008.03.019 Crossref $\bullet$ PubMed $\bullet$ Google Scholar

Cooper, C. E., Schaer, D. J., Buehler, P. W., Wilson, M. T., Reeder, B. J., Silkstone, G., Svistunenko, D. A., Bulow, L., \& Alayash, A. I. (2013). Haptoglobin binding stabilizes hemoglobin ferryl iron and the globin radical on tyrosine $\beta 145$. Antioxidants \& Redox Signaling, 18(17), 2264-2273. doi:10.1089/ars.2012.4547

Crossref $\bullet$ PubMed $\bullet$ PMC • Google Scholar

Dotsenko, O. I., \& Troshchynskaya, Y. A. (2014). Role of AMP catabolism enzymes in the energetic status of erythrocytes under conditions of glucose depletion [Rol' fermentov katabolizma AMR $v$ jenergeticheskom statuse jeritrocitov $v$ uslovijah ih istoshhenija po gljukoze]. Biosystems Diversity, 22(1), 46-52. doi:10.15421/011406 [In Russian] Crossref $\bullet$ Google Scholar

ISSN 1996-4536 (print) • ISSN 2311-0783 (on-line) • Біологічні Студії / Studia Biologica • 2021 • Том 15 / № 4 • С. 3-16 
Dotsenko, O.I., Taradina, G. V., \& Voronych, M. V. (2018). Enzyme protection systems of erythrocytes in conditions of ascorbate recirculation and oxidative loading. Regulatory Mechanisms in Biosystems, 9(4), 584-590. doi:10.15421/021887

Crossref $\bullet$ Google Scholar

Dotsenko, O. I., Mykutska, I. V., Taradina, G. V., \& Boiarska, Z. O. (2020). Potential role of cytoplasmic protein binding to erythrocyte membrane in counteracting oxidative and metabolic stress. Regulatory Mechanisms in Biosystems, 11(3), 455-462. doi:10.15421/022070 Crossref $\bullet$ Google Scholar

Everse, J., Johnson, M. C., \& Marini, M. A. (1994). [36] Peroxidative activities of hemoglobin and hemoglobin derivatives. Methods Enzymology, 231, 547-561. doi:10.1016/00766879(94)31038-6

Crossref • Google Scholar

Huo, S., Lei, X., He, D., Zhang, H., Yang, Z., Mu, W., Fang, K., Xue, D., Li H., Li, X., Jia, N., Zhu, H., Chen, C., \& Yan, K. (2021). Ferrous hemoglobin and hemoglobin-based oxygen carriers acting as a peroxidase can inhibit oxidative damage to endothelial cells caused by hydrogen peroxide. Artificial Organs, 00, 1-11. doi:10.1111/aor.14009

Crossref $\bullet$ PubMed $\bullet$ Google Scholar

Kosmachevskaya, O. V., \& Topunov, A. F. (2018). Alternate and additional functions of erythrocyte hemoglobin. Biochemistry(Moscow), 83(12-13), 1575-1593. doi:10.1134/S0006297918120155 Crossref $\bullet$ PubMed $\bullet$ Google Scholar

Liu, Y., Lv, H., Wang, B., Yang, D., \& Zhang, Q. (2020). Modelling and analysis of haemoglobin catalytic reaction kinetic system. Mathematical and Computer Modelling of Dynamical Systems, 2020, 26(4), 306-321. doi:10.1080/13873954.2020.1771379

Crossref $\bullet$ Google Scholar

Paco, L., Galarneau, A., Drone, J., Fajula, F., Bailly, C., Pulvin, S., \& Thomas, D. (2009). Catalaselike activity of bovine met-hemoglobin: Interaction with the pseudo-catalytic peroxidation of anthracene traces in aqueous medium. Biotechnology Journal, 4(10): 1460-1470. doi:10.1002/biot.200900100

Crossref $\bullet$ PubMed $\bullet$ Google Scholar

Ratanasopa, K., Strader, M. B., Alayash, A. I., \& Bulow, L. (2015). Dissection of the radical reactions linked to fetal hemoglobin reveals enhanced pseudoperoxidase activity. Frontiers in Physiology, 6, 39. doi:10.3389/fphys.2015.00039

Crossref $\bullet$ PubMed $\bullet$ PMC $\bullet$ Google Scholar

Reeder, B. J. (2010). The redox activity of hemoglobins: from physiologic functions to pathologic mechanisms. Antioxidants and Redox Signaling, 13(7), 1087-1123. doi:10.1089/ars.2009.2974 Crossref • PubMed • Google Scholar

Reeder, B. J. (2017). Redox and peroxidase activities of the hemoglobin superfamily: relevance to health and disease. Antioxidants and Redox Signaling, 26(14), 763-776. doi:10.1089/ ars.2016.6803

Crossref $\bullet$ PubMed $\bullet$ Google Scholar

Shatalov, V. M. (2012). Mechanism of the biological impact of weak electromagnetic fields and the in vitro effects of blood degassing. Biophysics, 57(6), 808-813. doi:10.1134/ S0006350912060152

Crossref • PubMed • Google Scholar

Shatalov, V. M., Filippov, A. E., \& Noga, I. V. (2012). Bubbles induced fluctuations of some properties of aqueous solutions. Biophysics, 57(4), 421-427. doi:10.1134/S0006350912040161

Crossref $\bullet$ PubMed $\bullet$ Google Scholar

Svistunenko, D. A., Dunne, J., Fryer, M., Nicholls, P., Reeder, B. J., Wilson, M. T., Bigotti, M. G., Cutruzzolà ,F., \& Cooper, C. E. (2002). Comparative study of tyrosine radicals in hemoglobin and myoglobins treated with hydrogen peroxide. Biophysical Journal, 83(5), 2845-2855. doi:10.1016/S0006-3495(02)75293-4

Crossref • PubMed • PMC • Google Scholar

ISSN 1996-4536 (print) •ISSN 2311-0783 (on-line) • Біологічні Студії / Studia Biologica • 2021 • Том 15 / № 4 • C. 3-16 
Uchida, T., Liu, S., Enari, M., Oshita, S., Yamazaki, K., \& Gohara, K. (2016). Effect of $\mathrm{NaCl}$ on the lifetime of micro- and nanobubbles. Nanomaterials, 6(2), 1-10. doi:10.3390/nano6020031 Crossref $\bullet$ PubMed $\bullet$ PMC $\bullet$ Google Scholar

Vlasova, I. (2018). Peroxidase activity of human hemoproteins: keeping the fire under control. Molecules, 23(10), 2561. doi:10.3390/molecules23102561

Crossref $\bullet$ PubMed $\bullet$ PMC $\bullet$ Google Scholar

Widmer, C. C., Pereira, C.P., Gehrig, P., Vallelian, F., Schoedon, G., Buehler, P.W., \& Schaer, D. J. (2010). Hemoglobin can attenuate hydrogen peroxide-induced oxidative stress by acting as an antioxidative peroxidase. Antioxidants and Redox Signaling, 12 (2), 185-198. doi:10.1089/ ars.2009.2826

Crossref $\bullet$ PubMed $\bullet$ Google Scholar

Witting, P. K., Mauk, A. G., \& Lay, P. A. (2002). Role of tyrosine-103 in myoglobin peroxidase activity: kinetic and steady-state studies on the reaction of wild-type and variant recombinant human myoglobins with $\mathrm{H}_{2} \mathrm{O}_{2}$. Biochemistry, 41(38), 11495-11503. doi:10.1021/bi025835w Crossref $\bullet$ PubMed $\bullet$ Google Scholar

\title{
ПЕРОКСИДАЗНА АКТИВНІСТЬ ГЕМОГЛОБННУ ЕРИТРОЦИТІВ ЗА ДІЇ НИЗЬКОЧАСТОТНОЇ ВІБРАЦІї
}

\author{
О. І., Доценко, Г. В., Тарадіна, А. М., Міщенко \\ Донецький національний університет імені Василя Стуса \\ вул. 600-річчя, 21, Вінниця 21021, Україна
}

Вступ. Як гемопротеїн, гемоглобін за наявності окислювальних еквівалентів, таких як $\mathrm{H}_{2} \mathrm{O}_{2}$, може діяти як пероксидаза з дуже високим окислювальним потенціалом. У ході цих реакцій гемоглобін утворює фрорми з високооокисненим залізом $\left(\mathrm{Fe}^{\mathrm{IV}}\right)$ та радикали глобіну, що мають високу окисну активність і $є$ токсичними для клітин. Крім того, пероксидазна активність може свідчити про будь-які структурні зміни, які могли статися в молекулі гемоглобіну внаслідок хімічних модифікацій. У роботі проаналізовано експериментальні дані щодо впливу низькочастотної вібрації на пероксидазну активність гемоглобіну еритроцитів, вивчення кінетики та пошуку кінетичних параметрів пероксидазної реакції за участю гемоглобіну.

Матеріали та методи. Суспензію еритроцитів піддавали дії вібрації протягом 3-х годин в інтервалі частот від 8 до 32 Гц, амплітудами 0,5 \pm 0,04 та 0,9 0,08 мм. Через певні проміжки часу в лізатах клітин визначали пероксидазну активність гемоглобіну та вміст його лігандних форм. Окремо проведено експерименти, що дають змогу дослідити механізм і розрахувати кінетичні параметри пероксидазної реакції.

Результати. Проаналізовано експериментальні дані щодо впливу низькочастотної вібрації на пероксидазну активність гемоглобіну еритроцитів. Досліджено кінетику реакції окиснення п-фенілендіаміну гемоглобіном еритроцитів. 3'ясовано, що пероксидазне окиснення проходить за механізмом типу пінг-понг. Знайдено кінетичні параметри пероксидазної реакції за участю гемоглобіну. Досліджено зміну кінетичних параметрів після двогодинного впливу середовища інкубування і низькочастотної вібрації. Запропоновано можливий механізм дії гемоглобіну в реакціях окиснення за участю $\mathrm{H}_{2} \mathrm{O}_{2}$.

ISSN 1996-4536 (print) • ISSN 2311-0783 (on-line) • Біологічні Студії / Studia Biologica • 2021 • Том 15 / № 4 • С. 3-16 
Висновки. Будь-який вплив, що ініціює утворення метгемоглобіну, призводить до росту пероксидазної активності гемоглобіну завдяки залучення останнього до псевдопероксидазного циклу й утворення токсичних високореакційних глобінових радикалів. Високий вміст оксигемоглобіну в клітині, що спостерігають за вібрації в інтервалі частот 16-32 Гц, амплітудою 0,9 \pm 0,08 мм, може запобігти його окисленню і вступу до псевдопероксидазного циклу.

Ключові слова: лігандні форми гемоглобіну, ензиматична кінетика, кінетичні константи, псевдопероксидазний цикл, гем, гіпоксія, п-фенілендіамін 